\title{
Correction to: Why is Poverty Lower in Rural America According to the Supplemental Poverty Measure? An Investigation of the Geographic Adjustment
}

\author{
José D. Pacas ${ }^{1}\left[\right.$. David W. Rothwell ${ }^{2}[$
}

Published online: 9 October 2020

(c) Springer Nature B.V. 2020

\section{Correction to: Population Research and Policy Review https://doi.org/10.1007/s11113-020-09612-9}

In the original publication of this article, the article title has been mentioned incorrectly. The correct title provided in this correction.

Publisher's Note Springer Nature remains neutral with regard to jurisdictional claims in published maps and institutional affiliations.

The original article can be found online at https://doi.org/10.1007/s11113-020-09612-9.

José D. Pacas

pacas002@umn.edu

1 Institute for Social Research and Data Innovation, University of Minnesota, Minneapolis, USA

2 School of Social and Behavioral Health Sciences, Oregon State University, Corvallis, USA 